\title{
Energetic Refurbishment of Historic Brick Buildings: Problems and Opportunities
}

\author{
Jurgis Zagorskas ${ }^{1}$, Gražvydas Mykolas Paliulis ${ }^{2}$, Marija Burinskiené ${ }^{3}$, Jūratė Venckauskaite ${ }^{4},{ }^{1-4}$ Vilnius Gediminas \\ Technical University, Torben Valdbjørn Rasmussen ${ }^{5},{ }^{5}$ Danish Building Research Institute, Aalborg University
}

\begin{abstract}
Building standards for energy effectiveness are increasing constantly and the market follows these changes by constructing new buildings in accordance with standards and refurbishment of the existing housing stock. Comprehensive trends in European construction market show tremendous increase in building retrofit works. It can be predicted that after the end of this decade, more than half of the construction works in European cities will be taking place in existing buildings, pushing the construction of new buildings to a less important role. Such a growth in building refurbishment works is creating a demand for suitable materials, retrofitting techniques and research. The differences between refurbishment of new-build projects and historical or valuable buildings are insufficiently recognized - mostly the buildings without further cultural preservation requirements are studied. This article covers the theme of refurbishment measures in historical buildings - the specific measures like inside insulation which are allowed due to the valuable façade or other heritage preservation requirements. An overview of other innovative methods for energy saving in existing buildings and their potential is given.
\end{abstract}

Keywords - building energy performance, energy efficiency measures, historic buildings, refurbishment / retrofit.

\section{INTRODUCTION}

Buildings are the localized tool of all political, economic, social, religious and cultural human activities; they support numerous functional needs, express historic preferences, contemporary choices and future visions of the population. A city's identity is reflected in the form of major government buildings, embassies, museums and other monumental buildings, and even housing districts. The presence or absence of these buildings, their construction or demolition, their cost and their ownership, their name and their marketing, as well as their accessibility and use - all these factors reflect local and national preferences, generate local identities, and often determine future building decisions. As political, economic, and social contexts change, the built environment keeps track of a location's history: political collapses, wars, or forced migrations. [1]

In recent decades, the role of culture and history has often become a driving factor in the process of urban regeneration. The focus on culture and history as factors in regional transformation has been particularly extensive in response not only to competitiveness among cities but also to sustainability requirements. [2] Creative cities are currently working on how to improve the interaction between building regeneration, economic development and social renewal in order to achieve more comprehensive development of the city. [3-5]
In cities of the Baltic Sea Region (BSR) among other historical tracks the traces of the Hanseatic League clearly denominate. The "German Hanse" greatly influenced the development of BSR towns starting from the XIV century leaving its footprint of characteristic red brick buildings in the cities of most BSR countries. [6] Most remaining historic buildings today have mortar construction and authentic facades and decorative elements which are listed amongst valuable characteristic traits of the buildings and have to be preserved.

From the other side, historic buildings were built in times when energy performance standards of the buildings and the lifestyles of inhabitants were not as challenging as today. People used natural wood or coal heating systems, they were used to colder temperatures during the winter season and their understanding of comfort was different from modern understanding. This creates the need to retrofit historic buildings to suite modern standards.

From the great oil crisis in the 1960-ies, the standards for building energy performance were raised constantly and the gap between existing previously built and newly constructed buildings was increasing also (Fig. 1).

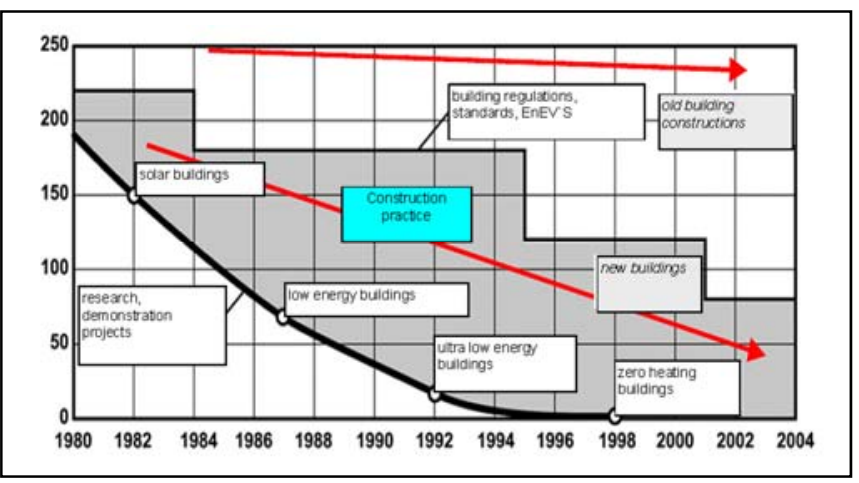

Fig. 1. Increasing gap between energy performance standards and existing housing stock (from presentation in $\mathrm{Co}_{2} \mathrm{OlBricks}$ project forum given by prof. R. Paggue, Dresden University of Technology).

Today there are around 2 billion households that meet modern comfort standards, set by economically developed countries. By 2050 1-1.5 billion more modern households will emerge in the world. It can become an impulse to greatly reconstruct or even demolish remaining historically valuable buildings or buildings that contribute to local identity. Often demolishment and rebuilding costs less than proper retrofit of the existing building and the achieved energy performance is better with less investment. However modern buildings often lack the unique appearance and identity, they resemble the 
global culture and international architectural style. Retrofitted buildings also often lose their unique outer appearance because outside insulation is applied and façade materials and details are hidden by the cover of insulation layer and modern finishing. To intercept these trends and to find alternatives, the EU is currently running a few international projects. One of the projects finalizing this year granted under the "Priority1: Fostering Innovations" of the Baltic Sea Region Programme 2007 - 2013 is " $\mathrm{Co}_{2}$ olBricks - Climate Change, Cultural Heritage \& Energy Efficient Monuments" initiated in order to find ways to reduce energy consumption in historical buildings without destroying their cultural value and identity. The project aims to find common solutions to combine the needs of climate protection with technical, administrative and historically adequate approaches to fulfill the necessary $\mathrm{CO}_{2}$ reduction aims [7].

\section{A. Overview of Related Research}

There were many attempts to find the most effective retrofit measures like EnergyPlus program tool [8], a multi-objective optimization model to assist stakeholders in the definition of intervention measures aimed at minimizing energy use in the building in a cost effective manner, while satisfying the occupant needs and requirements [9], the scalable methodology based on Bayesian calibration of calibrated normative models which can correctly evaluate energy retrofit options [10], the framework for handling the uncertainties associated with the prediction of energy savings in the retrofit analysis of a housing stock [11], and others [12-18].

There is a lack of understanding of historical building performance in industry and in policy, and a lack of connection between good research, standards, certification processes, guidance and practice. There is significant uncertainty with regard to the application of models and performance simulation software for this class of buildings. Some methods for assessing traditional buildings are inappropriate and give incorrect results, and some are misapplied and thus give false confidence in some measures. Traditional buildings often perform better in terms of heat loss through the fabric than as stated in standard models and assessment methods. This means that the likely paybacks from some retrofit measures, such as solid wall insulation, may be less than assumed. Traditional buildings require different assessment and practice with regard to the control of moisture in buildings, which is vital for fabric and human health.

\section{DESCRIPTION OF THE PROBLEM}

The growth in building refurbishment works is creating a demand for suitable materials, retrofitting techniques and research. The differences between refurbishment of new-build projects and historical or valuable buildings are insufficiently recognized - mostly the buildings without further cultural preservation requirements are studied.

Energy and sustainability are a hard challenge in building heritage, both the technical solutions in order to solve impact of energy conservation and aspect of conservation and maintenance of architectural heritage [19]. Energy efficiency and architectural heritage of brick buildings are two controversial topics. It is important to address these two issues so that the obtained result can meet today's requirements of energy efficiency and, at the same time, promote the preservation of historical buildings for future generations [20]. Only professionals, who are able to measure and analyze the actual heat consumption and heat transfer data, determine the moisture effects on historical brick buildings and recommend energy efficiency measures, can accomplish this. Currently developed simulation and visualization methods and measurement technologies can assist energy managers at different stages of their activity and have the potential to achieve energy savings on a large scale [10, 20, 21].

The energy consumption for heating and cooling the inside takes around $45 \%$ of the energy consumed in buildings (see Fig. 2). Other great energy losses happen in heating the water, lights and electronics, refrigeration and cooking which are not related to retrofitting directly, except the electronics where energy efficient bulbs and intelligent systems for saving electricity can be applied to cut overall energy use by $2-3 \%$.

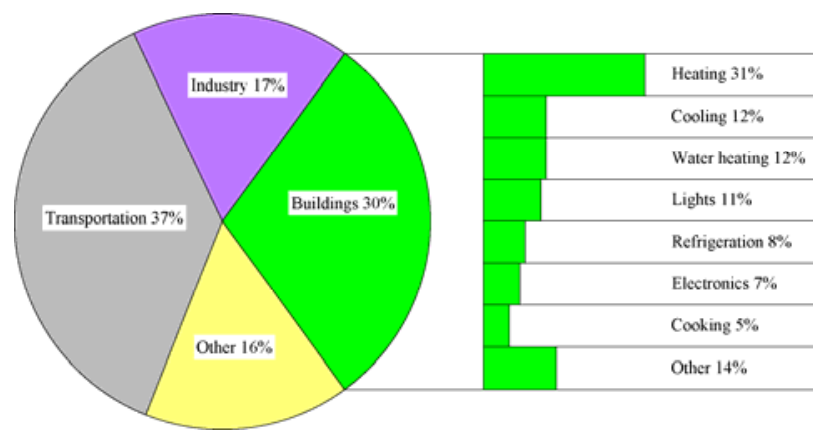

Fig. 2. Energy consumption in general and in buildings of European countries [22-24]

Energy efficiency can be greatly improved without touching the building construction - through optimization of the performance of the building envelope and intelligent operation and management of a HVAC (Heating, Ventilation and Air Conditioning) system $[7,25,26]$, changing the doors and windows, improving building air tightness, etc. High energy performance buildings feature airtight building envelopes with high levels of thermal resistance and have control over the flows of heat, air, and moisture into and out of the building. Historic buildings built before current building codes in most cases have high levels of air leakage and inadequate insulation. Both issues increase heating and cooling losses and demands on heating, ventilation, and air-conditioning systems and decrease occupant comfort and indoor air quality. Air leakage can account for a high percentage of heating and cooling bills in an especially leaky house, and houses built before 1980 often have little or no wall insulation. Given that walls can represent most of the building envelope area, ensuring that walls have proper levels of insulation is an essential part of any historic building energy retrofit [27]. Post-insulation of outer walls is the most challenging and most energy effective measure for historic building. The retrofit of 
interior insulation is commonly implemented to improve energy performance of these buildings, while maintaining their often historic exterior appearance [28].

\section{A. Specifics of Baltic Sea Region}

BSR countries, as well as all northern and middle European countries have a decreasing population and the population is increasing only through the immigration process and only in the most economically developed countries like Germany, Denmark, Sweden, Norway and the Netherlands. Nevertheless, the number of building area per person is increasing with the rise of living standards. Energy price at the same time is increasing and this creates a big concern in society on energy saving measures in buildings. About $30 \%$ of net consumed energy is consumed in buildings and in BSR countries with cold and medium-cold climate $30-40 \%$ of it goes to heating (Fig. 2). [22, 23] In the houses built before 1980 , energy consumption for heating is usually two and more times greater than in modern buildings built from the year 2000. Eg. in Denmark the average energy consumption for heating of modern houses (constructed after 2000) is $\sim 100$ $\mathrm{kWh} / \mathrm{m}^{2}$ per year and less and in the houses built before 1980 it is $200 \mathrm{kWh} / \mathrm{m}^{2}$ per year and more. [24] In less economically developed BSR countries these numbers vary even more - the difference is up to 3 times, because the old buildings are retrofitted very slowly and most of them are still waiting for energy saving measures to be applied.

\section{ENERGETIC REFURBISHMENT MEASURES FOR HISTORIC BRICK BUILDINGS}

In the refurbishment process of historic buildings there needs to be a compromise between payback period, comfort level, and preservation of historic authenticity of the building. Increasing energetic performance of the building usually means that some valuable details of the building are lost or replaced by imitations. Fig. 3 shows a typical example when the building was insulated from the outside to increase u-value of outer walls, and after such refurbishment lost attractiveness and historic character.

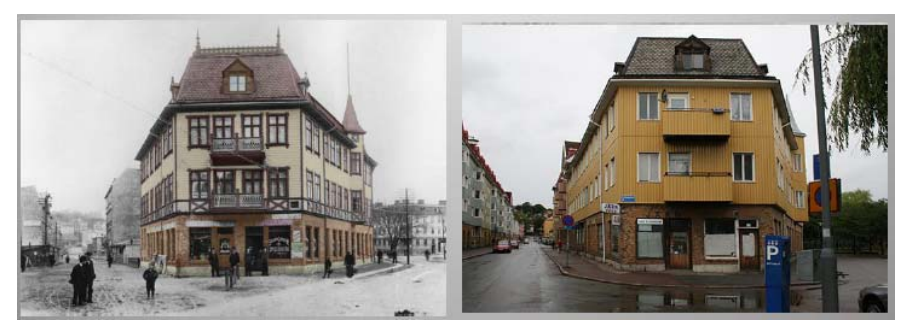

Fig. 3. Example of refurbished building when energy performance was increased to meet modern standards, but the authentic look of the building was destroyed.

The problem of outside insulation is important and topical for historic buildings with brick facades. Dominance of brick buildings characterizes most of the historic town centers in the Baltic Sea Region. There are many outside insulation construction systems with fake bricks existing in the market but none of the imitations have an appearance close enough or similar to that of authentic bricks.

Modern insulation materials would make it possible to insulate buildings from the inside without losing much space. It is enough to put $3 \mathrm{~cm}$ of VIP (vacuum insulation panel) or Aerogel to achieve the same u-value as with $15 \mathrm{~cm}$ of mineral wool or polystyrene. The construction adds $2 \mathrm{~cm}$ of thickness (usually $10 \mathrm{~mm}$ OSB are fixed from both sides of VIP or Aerogel panels) and thus it results in $5 \mathrm{~cm}$ along the whole perimeter of the outside walls. It is not a great loss, but the problem such materials create is moisture and condensation points. The walls of historic buildings in northern climates have to be well ventilated and warm to some degree to let the moisture evaporate from the construction and not to be trapped in the pores of the bricks or other construction material. Too much insulation from the inside will result in moisture buildup in the outside walls. Moist porous materials during freezethaw cycles start to disintegrate. Modern materials with super high $\mathrm{u}$-value have no breathing propensity - they create a barrier for vapor and humidity. Commercial products and developed construction systems exist that solve these problems, but such systems are costly and usually lead to greater space loss than already mentioned.

During work sessions, experts from the $\mathrm{Co}_{2}$ olBricks project analyzed measures available in the energetic refurbishment of historic brick buildings and worked on research of the effects of such measures. Experts concluded that there are quite a few measures as a result of which a significant change of u-values of historic brick buildings is made. Each historic building usually has its own specifics, but some general statements can be made about historical brick buildings in BSR:

- the standard BSR historic building is 3-7 stories tall;

- $\quad$ it usually has $45-90 \mathrm{~cm}$ thick solid brick wall;

- it usually has wooden ceilings and roof construction;

- the roof is usually covered with traditional tiling and has to have at least $35^{\circ}$ incline.

BSR is a cold climate zone and the windows in historic buildings are traditionally small. Usually the largest energy losses happen in the roof and walls. Even in case the wall thickness is $80 \mathrm{~cm}$ and more, the biggest surface faces the outside, and thus great energy losses are found here. Fig. 4 shows the average energy losses in a typical historic brick building in BSR.

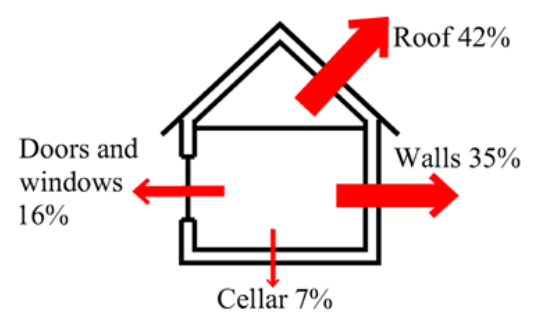

Fig. 4. Energy losses in typical historic brick building in BSR. 
$\mathrm{Co}_{2}$ olBricks project experts have made a list of the most effective measures in energetic refurbishment of historic brick buildings (Table 1). Even without expert conclusions, the most cost effective measures are found by the users of the buildings - simple measures of sealing the windows and doors to make the building airtight are the most popular in all colder climate countries.

TABLE I

MOST EFFECTIVE MEASURES FOR ENERGETIC REFURBISHMENT OF HISTORIC BRICK BUILDINGS IN BSR

\begin{tabular}{|c|c|c|}
\hline Number & $\begin{array}{c}\text { Rating given } \\
\text { by } \\
\mathrm{Co}_{2} \mathrm{olBricks} \\
\text { project experts }\end{array}$ & Energy saving measure \\
\hline 1 & 30 & New windows \\
\hline 2 & 29 & Post insulation of sloped ceilings \\
\hline 3 & 24 & Improving building air tightness \\
\hline 4 & 23 & Internal post-insulation of outer walls \\
\hline 5 & 20 & Heat Pumps \\
\hline 6 & 17 & $\begin{array}{l}\text { Energy saving light bulbs, } \\
\text { Daylight controlled lighting }\end{array}$ \\
\hline 7 & 15 & $\begin{array}{l}\text { Energy efficient secondary glazing on } \\
\text { windows }\end{array}$ \\
\hline 8 & 13 & Post insulation of cellar ceiling, cellar walls \\
\hline 9 & 11 & Central control of electrical components \\
\hline 10 & 11 & Radiating heat \\
\hline 11 & 9 & Improving heat production/boiler \\
\hline 12 & 8 & Wall tempering (research is in progress) \\
\hline 13 & 7 & Convector heating systems \\
\hline 14 & 6 & Solar water heating \\
\hline 15 & 5 & Regulated ventilation system \\
\hline
\end{tabular}

\section{EXAMPLES OF REFURBISHED BUILDINGS FROM BSR}

$\mathrm{Co}_{2} \mathrm{OlBricks}$ project partners were taking part in the refurbishment process of many buildings with high historical value. The refurbishment of historic buildings and bringing them to modern energy performance standards is financed by governmental organizations or by private initiatives, but in most cases requires subsidies. In all cases EU funds and other governmental financial support programs were used, otherwise the refurbishment works had too long a pay-back period to be attractive to private investors.

One of the typical examples is the Kavalergården building refurbishment in the outskirts of Copenhagen, Denmark (Fig. 5). The building was constructed in 1877 as part of an architectural ensemble of the Bernstorff palace. Before recent reconstruction, the building had deteriorated and it was decided to renovate it and increase energy performance. Refurbishment works included change of roof tiling, roof insulation, use of modern lanterns, change of regular window glass to reflective glass, change of doors, and installation of an effective modern lighting system. According to theoretical calculations, the energy savings on heating should decrease by $22 \%$. The measurements done after one year of functioning of the refurbished building indicated that the energy savings were only $14 \%$. More measurements and research will be done in the future to see the causes of energy performance lower than expected, but generally the theoretical calculations give too optimistic results.

The energy consumption for space heating has varied from 109 to $211 \mathrm{kWh} / \mathrm{m}^{2}$ over a 10 year period before the changed use of Kavalergården in 2009. The shift in level of space heating consumption in 2002 is due to installation of a new and more energy-efficient gas boiler. In 2008/2009 the energy consumption is very low due to the uninhabited period. From 2009/2010 until 2010/2011, when the energy upgrade was carried out, the space heating consumption was approximately the same as in the period 2003 to 2008 before the upgrade. From 2010/2011 to $2011 / 2012$ the energy consumption decreases form 146 to $126 \mathrm{kWh} / \mathrm{m}^{2}$ corresponding to a total of $35600 \mathrm{kWh} /$ year. This could indicate the effect of the energy upgrade, but this must be confirmed by measurements of energy consumption in the years to come.

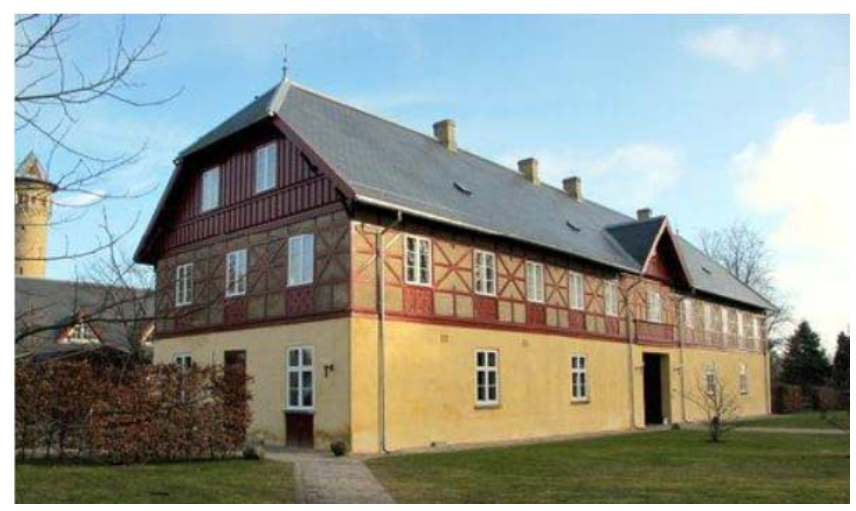

Fig. 5. Kavalergården building after refurbishment

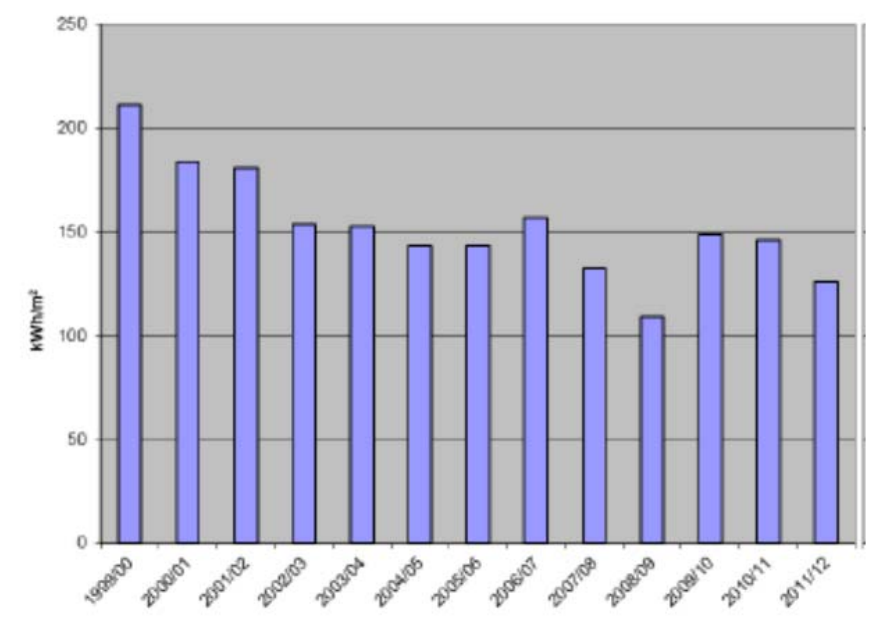

Fig. 6. Energy consumption for space heating in Kavalergården building before and after refurbishment

Another example - energetic refurbishment of multi-flat house Emehuset in Copenhagen, Denmark (Fig. 6), when the main measure taken was insulation of outer walls and roof. The exterior of this former poorhouse in solid masonry, with 
two-light windows with small panes and slate roof is categorized as worthy of preservation by the municipality.

In Denmark, this type of building dates mainly from the period of 1850 to 1920 and accounts for approximately $20 \%$ of all dwellings in Denmark. The majority of the buildings have wooden joist floors, but Elmehuset has concrete decks, which makes it ahead of its time. But the red masonry, the two-light windows with small panes and the slate roof are typical of Danish building tradition of this period. The exterior of this kind of building is often considered worthy of preservation at some level, and they are generally highly valued for their contribution to the uniqueness of the local environment.

Energy analysis of the building was carried out as part of the project in order to find ways to reduce the $\mathrm{CO}_{2}$ level whilst ensuring an indoor climate that matches the applicable guidelines and requirements in the Danish Building Regulations. An interdisciplinary working group consisting of the building owners (Municipality of Copenhagen), the authorities (Center for Building and Construction/ Center for City Design), the architects (Kant architects) and the consulting engineers (Klaus Nielsen Consulting Engineers) considered which solutions to use.

In the year 2009 it was concluded that the building needs renovation, the windows and plumbing needed replacement. Facades were considered valuable features of the building and it was prohibited to make outside insulation. The outlook of the building had to be kept the same to have the same style and appearance as the surrounding buildings. The building had $\mathrm{G}$ class of energy performance. The combined measures of roof insulation, changing of outside doors and windows, reinstallation of electricity cables, lighting system and plumbing, change of convectors and ventilation system, and inside insulation of outside walls in stairwells were applied. After refurbishment the building was certified for $\mathrm{C}$ class in energy performance.

There was a discussion raised when selecting the measures to be applied in this building. Consultants made calculations of energy benefits from each measure. Architects and engineers recommended internal insulation of facades with $200 \mathrm{~mm}$ mineral wool, which would fulfill the requirements of the Building Regulations, and that mechanically balanced ventilation was provided.

The fears of the administrator and the consultants concerning the internal insulation centered on the following:

- By how much the additional insulation reduces the floor area?

- Does additional insulation require balanced ventilation in all rooms?

- Is additional insulation cost-effective?

- How high is the risk of mold growth at a possible dew point on the inside of the old outer wall?

- Can the vapor barrier be watertight and remain so?

- How can cold bridges in the floors, the supporting and solid transverse partition walls be reduced?

An additional $200 \mathrm{~mm}$ of mineral wool insulation would reduce the accommodation area on a standard floor by approx. $40 \mathrm{~m}^{2}$ if in the form of a secondary wall of $290 \mathrm{~mm}$. This would give a remaining net floor area of $\left(1982 \mathrm{~m}^{2}-(3 \mathrm{x}\right.$ $\left.\left.40 \mathrm{~m}^{2}\right)\right)=1862 \mathrm{~m}^{2}$, equivalent to a reduction of approx. $6 \%$. This could have given problems for letting the premises, as it would reduce the income for a landlord, making the cost of additional insulation an expense which cannot be included in the cost-effectiveness calculations, but which could have major impact on the building owner. In this instance, a change in the thickness of the facade could prevent the reasonable and flexible interior design of several of the rooms intended for accommodation. Such a high level of insulation requires mechanically-balanced ventilation to be able to maintain air humidity at a level at which there is no risk of condensation in the structure, and the subsequent development of rot and mold growth.

The simulation of relative humidity in the wall structure was made (Fig. 7) which shows extremely high RH levels in the winter.
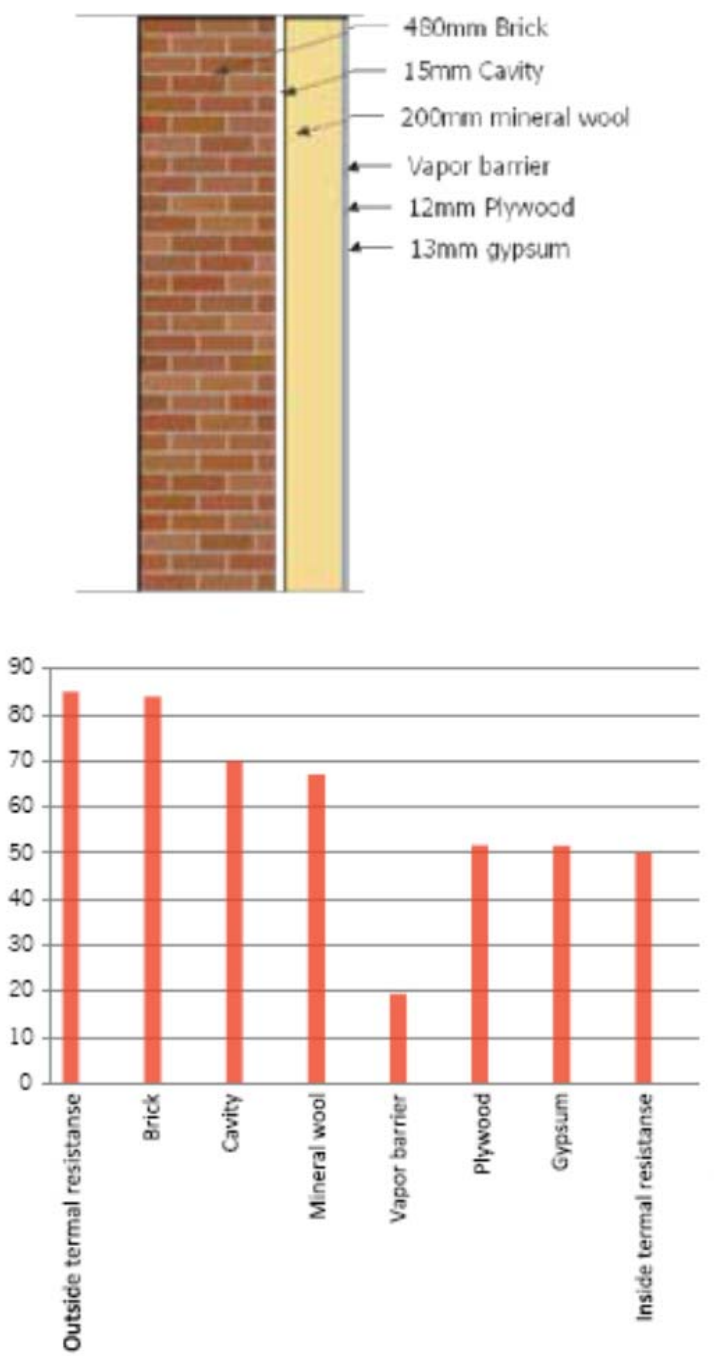

Fig. 7. Proposed construction of the wall and calculated RH levels in Elmehuset building after adding $200 \mathrm{~mm}$ internal insulation

Annual energy consumption in 2009 and before:

- Heating: 294,0 MWh

- Electricity: 108,0 MWh 
Total energy consumption: 402,0 MWh, corresponding to heat consumption: $107,9 \mathrm{kWh} / \mathrm{m}^{2}$. The building's energy consumption was classified as G2).

Annual energy consumption after refurbishment:

- Heating: 94,5 MWh

- Electricity: 87,0 MWh

Total energy consumption: $182,0 \mathrm{MWh}$, corresponding to heat consumption: $41,6 \mathrm{kWh} / \mathrm{m}^{2}$.

Very often wall insulation is not applied in historic building energy refurbishment. Storehouse refurbishment in Hamburg (Fig. 9) to suit the needs of a museum and exhibition center provides such an example. The energy in this project is saved mainly by an innovative HVAC system. The building had masonry walls $80 \mathrm{~cm}$ thick and more. In the basement there was enough floor space to install a modern HVAC system. Floor heating was installed in the ground floor. Modern windows with controlled air leakage allow air to come inside the building and as the air is heated it gradually rises to the roof through the central hall and comes out through the ventilation openings. There are infrared heaters on the ceilings on every floor working only when the room is in use. The cost of this reconstruction was 28 mill. $€$.

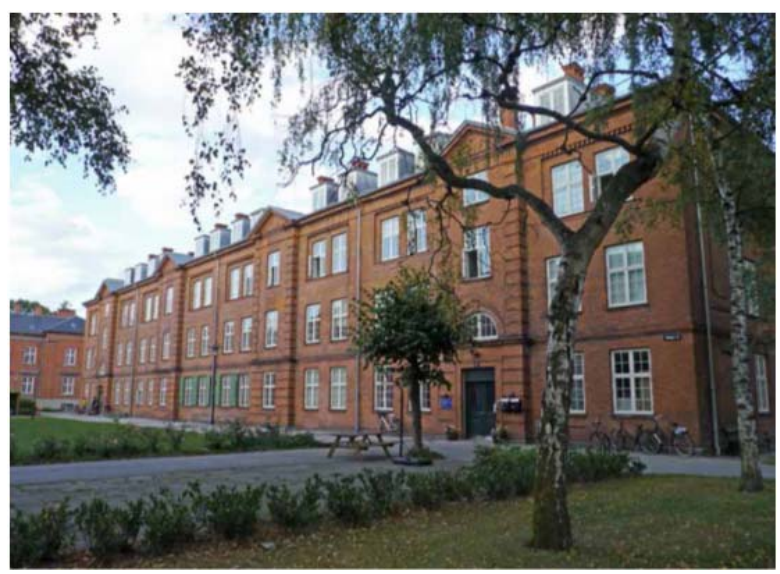

Fig. 8. Elmehuset building after refurbishment

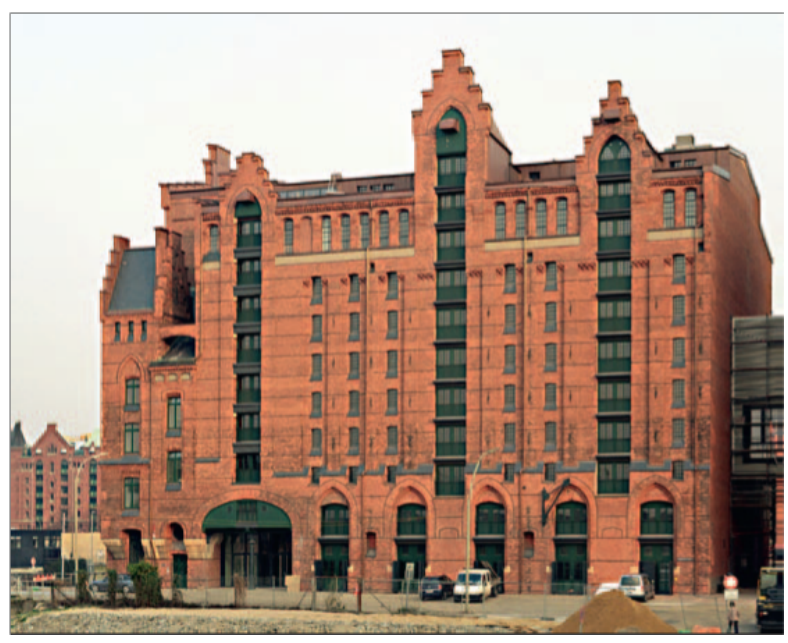

Fig. 9. Historic building reconstruction in Hamburg

\section{CONCLUSION}

The physical performance of the outside walls of historic buildings has to be checked with suitable methods. The main principle of applying external wall insulation structures is that the wall must be airtight and the water vapor permeability of structural layers must increase gradually towards the outside surface of the wall. A water vapor barrier may be needed near the inner surface of a wall. Regarding durability aspects of the wall, driving rain water leakages into wall structures are harmful. Water may enter the wall through connections, construction faults or during unprotected construction work. If the insulation material is foam plastic or other water vapor tight material, or if the insulation material is such that it can absorb very little moisture, or if there is no ventilation gap behind the façade, water leakages are very risky. Excessive moisture levels may cause mold to develop in the wall. This may also be a risk considering indoor air quality.

When upgrading historic building with regard to energy consumption, one must accept that it will also be a building in which the technical installations play a much greater role. Additional internal insulation cannot stand alone, but can have great effect on the overall energy performance of the building. A building's function and reliability are conditional on investing in mechanically-balanced ventilation, heat recovery systems and possibly the control of ventilation and windows to ensure an indoor climate that is acceptable in terms of moisture and comfort.

Increase of energy performance in historic buildings is limited by preservation requirements and in most cases it is impossible to achieve modern energy performance standards in historic buildings (Fig. 8). Energy performance certification for historic buildings is not mandatory at the moment, but the trend in Europe is such that it will become so in the nearest future. Currently there are proposals to include historic buildings in "Energy Performance of Buildings Directive" (EPBD) to make certification procedure for historic buildings obligatory [29]. The certification of historic buildings would give information to stakeholders and make the buildings more integrated in the market. This will lead to investigations and research of new methods for energy saving and increasing energy performance of these buildings.

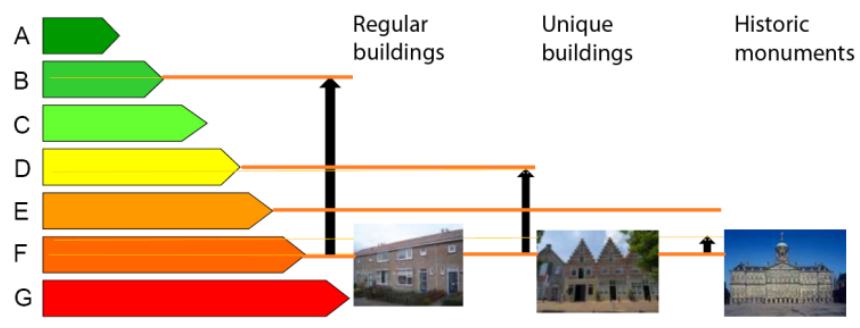

Fig. 10. Possibilities of energy performance increase for regular, unique and historic buildings (from presentation in $\mathrm{Co}_{2} \mathrm{OlBricks}$ project forum given by Marleen Spiekman).

Many buildings are not listed as heritage buildings, but still have an authentic look and contribute to the sense of a place's 
identity. Refurbishment works in these buildings must be done with the greatest care involving cultural heritage specialists.

\section{ACKNOWLEDGMENT}

This article was prepared within "Co2ol Bricks" project financed by Baltic Sea Region Programme 2007-2013. The illustrations from project forums (fig. 1, fig. 10) by prof. R. Paggue, Dresden University of Technology and M. Spiekman were used.

\section{REFERENCES}

1. Hein, C., Spaces of Identity in East European Cities. 2012.

2. Smith, M. and G. Richards, Routledge Handbook of Cultural Tourism. 2013: Routledge.

3. Sepe, M., Urban history and cultural resources in urban regeneration: a case of creative waterfront renewal. Planning Perspectives, 2013(ahead-of-print): p. 1-19.

4. Lähdesmäki, T., Politics of Cultural Marking in Mini-Europe: Anchoring European Cultural Identity in a Theme Park. Journal of Contemporary European Studies, 2012. 20(1): p. 29-40.

5. Martinez, N.M., City marketing and place branding: A critical review of practice and academic research. Journal of Town and City Management, 2012. 2(4): p. 369-394.

6. Jahnke, C., THE CITY OF LÜBECK AND THE INTERNATIONALITY OF EARLY HANSEATIC TRADE. The Hanse in Medieval and Early Modern Europe, 2012. 60: p. 37

7. Aste, N., R. Adhikari, and M. Buzzetti, ENERGY RETROFIT OF HISTORICAL BUILDINGS: AN ITALIAN CASE STUDY. Journal of Green Building, 2012. 7(4): p. 144-165.

8. Levine, M., et al., A Retrofit Tool for Improving Energy Efficiency of Commercial Buildings. ACEEE 2012 Summer Study, 2012.

9. Asadi, E., et al., Multi-objective optimization for building retrofit strategies: A model and an application. Energy and Buildings, 2012. 44: p. 81-87.

10. Heo, Y., R. Choudhary, and G. Augenbroe, Calibration of building energy models for retrofit analysis under uncertainty. Energy and Buildings, 2012. 47: p. 550-560.

11. Booth, A. and R. Choudhary, Decision making under uncertainty in the retrofit analysis of the UK housing stock: Implications for the Green Deal. Energy and Buildings, 2013.

12. Asadi, E., et al., A multi-objective optimization model for building retrofit strategies using TRNSYS simulations, GenOpt and MATLAB. Building and Environment, 2012. 56: p. 370-378.

13. Junghans, L., Sequential Equi-Marginal Optimization Method for ranking strategies for Thermal Building Renovation. Energy and Buildings, 2013.

14. Lapinskiene, V. and V. Martinaitis, The Framework of an Optimization Model for Building Envelope. Procedia Engineering, 2013. 57: p. 670-677.

15. Diakaki, C. and E. Grigoroudis, Applying genetic algorithms to optimize energy efficiency in buildings. Multicriteria Decision Aid and Artificial Intelligence: Links, Theory and Applications, 2013: p. 309.

16. Ma, Z., et al., Existing building retrofits: Methodology and state-of-theart. Energy and buildings, 2012.

17. Rysanek, A. and R. Choudhary, Optimum building energy retrofits under technical and economic uncertainty. Energy and Buildings, 2012.

18. Konstantinou, T. and U. Knaack, An approach to integrate energy efficiency upgrade into refurbishment design process, applied in two case-study buildings in Northern European climate. Energy and Buildings, 2013. 59: p. 301-309.

19. Fabbri, K., Energy incidence of historic building: Leaving no stone unturned. Journal of Cultural Heritage, 2013.

20. Hensley, J.E. and A. Aguilar, Improving Energy Efficiency in Historic Buildings. Vol. 3. 2012: Government Printing Office.

21. Costa, A., et al., Building operation and energy performance: Monitoring, analysis and optimisation toolkit. Applied Energy, 2013. 101: p. 310-316.

22. Group, W.B.D.D., World Development Indicators 2012. 2012: World Bank-free PDF.

23. Agency, I.E. Key World Energy Statistics-2012. 2012. IEA Paris, France.
24. Hensen, J. Building energy simulation: challenges and opportunities. in SIMUREX 2012-Conception optimisée du bâtiment par la SIMUlation et le Retour d'EXpérience. 2012. EDP Sciences.

25. Jung, D.K., et al., Optimization of Energy Consumption Using BIMBased Building Energy Performance Analysis. Applied Mechanics and Materials, 2013. 281: p. 649-652.

26. Xu, Z., et al., Performance Analysis and Comparison on Energy Storage Devices for Smart Building Energy Management. Smart Grid, IEEE Transactions on, 2012. 3(4): p. 2136-2147.

27. Roberts, S. and R. Stephenson, Measure Guideline: Wall Air Sealing and Insulation Methods in Existing Homes. 2012.

28. Ueno, K. and R. Van Straaten, Expert Meeting Report: Interior Insulation Retrofit of Mass Masonry Wall Assemblies. 2012: US Department of Energy, Energy Efficiency \& Renewable Energy.

29. European Commission, $7^{\text {th }}$ frame program, International project 3ENCULT "Efficient Energy for EU Cultural Heritage", "Proposal for the integration of historic buildings in the EPBD", http://www.3encult.eu/en/deliverables/Documents/WP7_D7.8_2013051 7_P12_Proposal_integration_Historic_Buildings_in_EPBD.pdf /last acessed 10-09-2013.

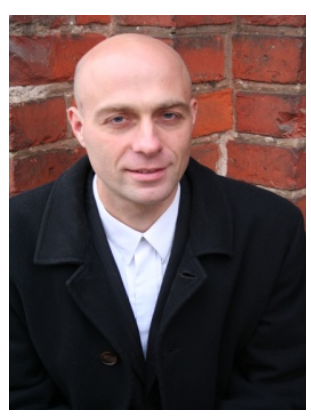

Jurgis Zagorskas has finished studies of architecture (2000, masters degree in Vilnius Gediminas Technical University), computer graphics, gained $\mathrm{PhD}$ degree in technology science (2008, VGTU).

Major field of study is sustainable urban development and building retrofits.

Author was working in Kaunas Municipality Enterprise for town planning as Project Manager, at the moment works in VGTU as an Associated Professor and researcher in Research Institute of Territorial Planning (Vilnius Gediminas Technical University (VGTU), Sauletekio al. 11, LT-10223 Vilnius, Lithuania). At the same time with the research and educative work is working as a free-lanced Architect and Town Planner.

Address: Saulètekio al.11, LT-10223 Vilnius, Lithuania

Phone: +370 52745072

E-mail: jurgis.zagorskas@gmail.com

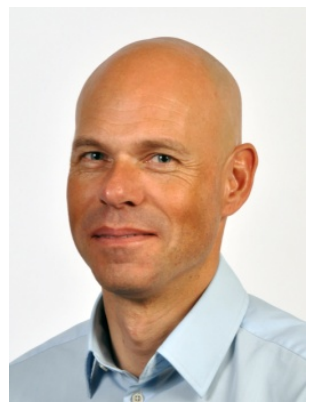

Torben Valdbjørn Rasmussen, MSc (CivEng), Ph.D, SENIOR RESEARCHER. Graduated in 1991 from the Technical University of Denmark, DTU, as a civil engineer with a M.Sc. in building physics. His Ph.D. study specialized in the mechanical behaviour of fibre-reinforced cement-based materials. After his Ph.D. he specialized in statics, material mechanics, building technology, building physics, modelling, experimental techniques and microscopy techniques describing the behaviour of building materials. As the project leader of an EU project entitled Improved Quality Assurance and Methods of Grouting Posttensioned Tendons, he had excellent results with the introduction of a new recipe for a non-bleeding grout demonstrated in full-scale tests. Since 1999, he has worked as a SENIOR RESEARCHER at SBi, AAU, where he specialises in building physics and adaption of the building environment to the future climate.

Danish Building Research Institute (SBi), Aalborg University Department of Construction and Health,

Address: A.C. Meyers Vænge 15, 2450 København SV., DK Danmark

Phone: +45 9940 2272,

e-mail: tvr@sbi.aau.dk 


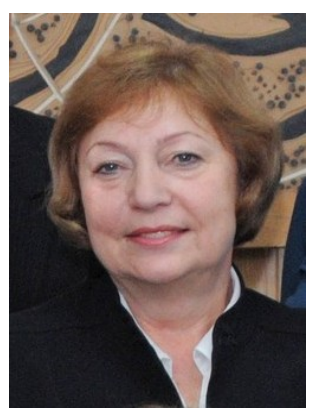

Marija Burinskiene is one of the first scientists, who started the research on sustainable development and sustainability as well as quality of life questions in Lithuania, like example of post socialistic countries. Head of urban engineering department, in Vilnius Gediminas Technical University. Chief of more than 30 Comprehensive Plans of municipalities of the Lithuanian cities and regions. Chief of more than 90 scientific research projects which clients are: Ministry of Environmental, Ministry of Transportation, Lithuanian State Department of Tourism and Municipalities. Since 1997 Marija Burinskiene became director of Research Institute of Territorial Planning and the incumbent this position part time until now. Certificate of Qualification: Granted a right to be in the position of the head of the project. Type of territory planning: master, detailed and special planning of territories.

Lecturing: Urban sustainable development- for PhD students; Management of urban development; Special transportation infrastructure; Planning of roads and streets network- Master degree students; Engineering Equipment of Urban Territories- Bachelor students.

Address: Saulètekio av. 11, LT-10223, Vilnius, Lithuania

Phone: +370 52744720 , Fax: +370 52370588

E-mail: marbur@vgtu.lt

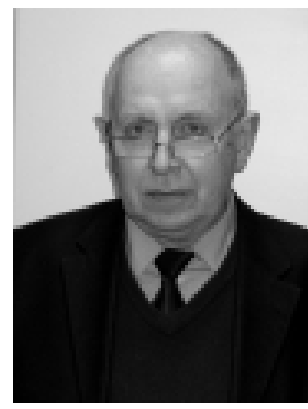

Gražvydas Mykolas Paliulis. Associated professor in Department of Urban Engineering of Vilnius Gediminas Technical University. Researcher of more than 15 Comprehensive Plans of municipalities of the Lithuanian cities and regions.

Lecturing: Urban Infrastructure; Urban Public

Transport; Traffic Organization and Safety; Transportation Infrastructure - Master degree students; Urban Transport - Bachelor students.

G. M. Paliulis started his teaching activity since year 1969.

Scientific research area: urban transport systems, traffic engineering, development of urban economies, management of urban processes; supervision of master papers.

Address: Sauletekio av. 11, LT-10223, Vilnius, Lithuania

Phone: +370 5 2744719, Fax: +370 52370588

E-mail: msk@,vgtu.lt

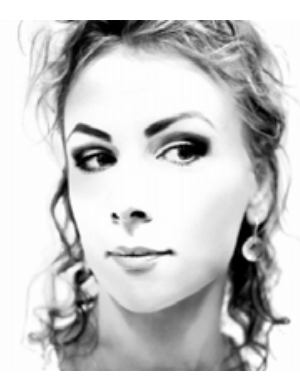

Jūratė Venckauskaitè 2004 has finished studies in Vilnius Gediminas Technical University (VGTU), bachelor if Civil engineering. Study programme - Urban Engineering, specialization - Management of Urban Economy; In 2006 - in VGTU, master of Civil Engineering, study programme Civil Engineering, specialization - Urban Engineering Information Systems. Doctoral dissertation "Analysis of Urban Sustainability Process and Quality of Life Evaluation" was prepared at VGTU in 2007-2011. The dissertation has been defended at the public meeting of the Council of Scientific Field of Civil Engineering on 20 December 2011.

From 2005 works as researcher in Research Institute of Territory Planning and from 2013 is associated professor in Department of Urban Engineering at VGTU. Has a Certificate of Qualification - granted a right to be in the position of the head of the project; type of territory planning: master, detailed and special planning of territories.

Scientific field: to analyze and model sustainable development processes on a state, regional or local level, evaluation of subjective and objective quality of life;

to value projects in an economical, ecological and social aspect, to invoke technical innovations in practical activity; cycling infrastructure and development

Address: Saulètekio av. 11, LT-10223, Vilnius, Lithuania

Phone: +370 5 2370576, Fax: +370 52370588

E-mail: vjurate@vgtu.lt 